\title{
Budgets of sediment nitrogen and carbon cycling in the shallow water of Knebel Vig, Denmark
}

\author{
Bente Aa. Lomstein ${ }^{1, *}$, Anna-Grethe U. Jensen ${ }^{1}$, Jens W. Hansen ${ }^{1}$, \\ Jane B. Andreasen ${ }^{1}$, Lars S. Hansen ${ }^{1}$, Jørgen Berntsen ${ }^{1}$, Helmar Kunzendorf ${ }^{2}$ \\ ${ }^{1}$ Department of Microbial Ecology, Institute of Biological Sciences, Aarhus University, Building 540, Ny Munkegade, \\ DK-8000 Aarhus C, Denmark \\ ${ }^{2}$ Environmental Science \& Technology Department, Gamma Dating Center, Risø National Laboratory, PO Box 49, \\ MIL-124, DK-4000 Roskilde, Denmark
}

\begin{abstract}
Sediment was sampled from a shallow coastal area (Knebel Vig. Denmark). The vertical distribution of pigments, $\mathrm{Pb}-210$ and $\mathrm{Cs}-137$ indicated that organic matter was mixed into the sediment. On an area basis, sediment acid hydrolyzable amino acids accounted for $24 \%$ of the particulate organic carbon pool and $53 \%$ of the particulate organic nitrogen pool. Similarly, porewater acid hydrolyzable amino acids were an important component of dissolved organic carbon and dissolved organic nitrogen ( 9 and $27 \%$, respectively). It was inferred that ribonuclesc acids potentially were an important component of dissolved organic nitrogen. The estimated efflux of dissolved organic nitrogen from the sediment was higher $\left(3.9 \mathrm{mmol} \mathrm{N} \mathrm{m}^{-2} \mathrm{~d}^{-1}\right)$ than the estimated efflux of dissolved inorganic nitrogen (<2 mmol $\mathrm{N} \mathrm{m}^{-2} \mathrm{~d}^{-1}$ ). The high efflux of dissolved organic nitrogen was explained by organic matter hydrolysis close to the sediment surface. The low rates of inorganic nitrogen efflux together with a high carbon oxidation rate suggested degradation of organic matter with a low average nitrogen content and possible bacterial nitrogen assimilation. This was further supported by mass balance calculations on nitrogen incorporation into microbial biomass. The calculated average $\mathrm{C} / \mathrm{N}$ ratio in the organic matter degraded suggested that only part of the sediment acid hydrolyzable amino acids were available for bacterial degradation. The efficiency of bacterial carbon incorporation was 0.33 and within the range previously encountered in sediments of Danish waters.
\end{abstract}

KEY WORDS: Sediment - Nitrogen Carbon · Cycling · Fluxes - Urea · Amino acids

\section{INTRODUCTION}

Shallow water sediments are sites where most organic matter mineralization in marine sediments takes place (Jargensen 1983). Information on mineralization processes in sediments can be drawn from different sources: one is from measurements of the efflux of mineralization products from the sediment and this method has been extensively discussed by Blackburn et al. (1996), another is the geochemical analysis of porewaters and sediment solid constituents combined with diagenetic modeling (e.g. Henrichs \& Farrington 1984, Burdige \& Martens 1990) and a third source of information is direct measures of the rate of break-

•E-mail: bente@pop.bio.aau.dk down of specific organic molecules (e.g. Christensen \& Blackburn 1980, Lomstein et al. 1989, Sugai \& Henrichs 1992). The organic matter pools available for microbial degradation in sediments are composites of dissolved organic matter (DOM) and are often quantified as either dissolved organic carbon (DOC) or dissolved organic nitrogen (DON). These pools are composed of a suite of known and unknown compounds that are generated from bacterial hydrolysis of particulate organic matter and accumulation of intermediate products of anaerobic degradation. Due to the lack of information on the composition of the DOM pool there is also incomplete information on the exact DOM components through which carbon and nitrogen are recycled. Similarly, there is a lack of information on factors regulating recycling and retention of carbon and nitrogen in sediments. 
The aim of the present study was to obtain detailed information on factors controlling organic carbon and nitrogen cycling with specific focus on the relation between the $\mathrm{C} / \mathrm{N}$ ratio in the organic matter degraded and bacterial nitrogen assimilation. The following pools were measured: particulate organic carbon (POC), particulate organic nitrogen (PON), sediment acid hydrolyzable amino acids $\left(\mathrm{THAA}_{\mathrm{s}}\right), \mathrm{DOC}, \mathrm{DON}$, porewater acid hydrolyzable amino acids $\left(\right.$ THAA $_{\mathrm{pw}}$ ) dissolved free amino acids (DFAA), urea and $\mathrm{NH}_{4}{ }^{+}$ In addition the rates of urea, alanine and glutamate turnover were measured and the total DFAA turnover was calculated. Carbon oxidation was measured as the $\Sigma \mathrm{CO}_{2}$ efflux from the sediment to the water column Finally, high resolution porewater profiles $(1.5 \mathrm{~mm})$ of DOC, DON and $\mathrm{NH}_{4}{ }^{+}$were used to calculate net diffusional fluxes of these solutes from the sediment to benthic primary producers and/or the water column.

\section{MATERIALS AND METHODS}

Sampling. Sediment was sampled at $4 \mathrm{~m}$ water depth in Knebel Vig, Denmark, on July 4, 1994, at a station with the coordinates $56^{\circ} 13.69^{\prime} \mathrm{N}, 10^{\circ} 27.46^{\prime}$ E. Knebel Vig is a small embayment $\left(2100 \mathrm{~m}^{2}\right)$ of the east coast of Kalø Vig. The sediment texture is silty sand and is further described in Christiansen et al. (1981). The bottom water temperature was $18.5^{\circ} \mathrm{C}$ and the salinity $24.3 \%$. Sediment was collected in Plexiglas cores $120 \mathrm{~cm}$ $3.6 \mathrm{~cm}$ i.d.) with a bar-core collector. The sediment was stored in the dark and at the in situ temperature until returning to the laboratory (within $1 \mathrm{~h}$ ). Twenty sediment cores were sectioned into $1.5 \mathrm{~mm}$ slices within the upper $7.5 \mathrm{~mm}$ of the sediment, into $4.5 \mathrm{~mm}$ sections in the $7.5-16.5 \mathrm{~mm}$ depth strata, $10.5 \mathrm{~mm}$ sections in the $16.5-58.5 \mathrm{~mm}$ zone and finally into one $30.0 \mathrm{~mm} \mathrm{sec}$ tion to a final depth of $88.5 \mathrm{~mm}$. The sediment from each depth stratum was thoroughly mixed and the head space above the sediment was replaced with $\mathrm{N}_{2}$.

Sediment characteristics. The following parameters were determined: specific density, water content, $\mathrm{Pb}$ 210 and $\mathrm{Cs}-137$ gamma-radiation activities, pigment

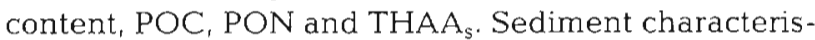
tics were measured at the depths described above, except that pigments were only measured to a final depth of $16.5 \mathrm{~mm}$ and THAA $_{\mathrm{s}}$ was only measured in every second sediment stratum.

Sediment specific density $\left(\mathrm{g} \mathrm{cm}^{-3}\right)$ was determined gravimetrically on triplicate $1 \mathrm{~cm}^{3}$ sediment samples and the water content $\left(\mathrm{ml} \mathrm{g}^{-1}\right)$ was determined as the weight loss from fresh sediment dried at $105^{\circ} \mathrm{C}$ for $24 \mathrm{~h}$.

$\mathrm{Pb}-210$ and Cs-137 activities were measured on dried sediment in a well-type Ge (Li) detector. As there was a simultaneous detection of U-decay series, these daughter activities (Ra-226, Pb-214, Bi-214) allowed a direct determination of supported $\mathrm{Pb}-210$ ( $\mathrm{Pb}-210_{\text {sup }}$ ).

Samples for pigment analysis were prepared in the following manner: acetone (Lichro solve, Merck 20) was added to $1 \mathrm{~cm}^{3}$ of frozen sediment to a final concentration of $90 \%(\mathrm{v} / \mathrm{v})$ in the porewater. The sediment was extracted for $72 \mathrm{~h}$ at $-20^{\circ} \mathrm{C}$ and in the dark and the sediment-acetone extract was gently shaken 3 or 4 times during extraction. Extracts were filtered through a $0.5 \mu \mathrm{m}$ Teflon micro filtration system (MFS 03JP05OAN) and $300 \mu \mathrm{l} \mathrm{TBAA}$ was added to $1 \mathrm{ml}$ acetone extract. TBAA was $1.5 \mathrm{~g}$ tetrabutylammonium acetate (Fluka 86849) + $7.7 \mathrm{~g}$ ammonium acetate (Fluka 09689) in $100 \mathrm{ml}$ Milli- $Q$ water; the TBAA solution was adjusted to $\mathrm{pH}$ 7.0. Chlorophyll $a$ and $b$ standards were obtained from Fluka (Fluka 25730 and 25740 , respectively). Pigment separations were performed using the following instrumentation: Waters 501 pumps, Waters 715 Ultra Wisp Sample processor, Waters 470 Scanning fluorescence detector (excitation $=430 \mathrm{~nm}$, emission $=630 \mathrm{~nm}$ ) and a Baseline data acquisition program (attenuation $=32$, gain $=\times 100$ ) . Separations were performed on a $25 \mathrm{~cm}$ Hypersil $5 \mathrm{C}_{18}$ column, ODS from Phenomenex. The gradient was a modification of that described in Mantoura \& Llewellyn (1983), as the pigments were obtained by a linear gradient elution from $100 \% \mathrm{~A}$ to $100 \% \mathrm{~B}$ in $20 \mathrm{~min}$, followed by an isocratic hold for $20 \mathrm{~min}$ at $100 \%$ B that was terminated by a 5 min linear gradient from $100 \%$ B to $100 \%$ A. Eluent A was $80 \%$ methanol $($ Merck 1.06007$)+15 \%$ Milli-Q water $+5 \%$ TBAA (v/v) and eluent B was $80 \%$ methanol $+20 \%$ acetone

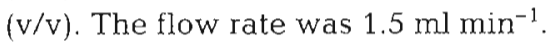

POC and PON were measured on dried, homogenized, $\mathrm{H}_{2} \mathrm{SO}_{3}$ treated sediment in a Carlo Erba NA $1500 \mathrm{HCN}$ analyser.

THAA $_{\mathrm{s}}$ was determined on $1 \mathrm{~cm}^{3}$ fresh sediment to which there was added $10 \mathrm{ml} 6 \mathrm{~N} \mathrm{HCl}$. Hydrolysis of the sediment sample was carried out at $110^{\circ} \mathrm{C}$ for $24 \mathrm{~h}$. After hydrolysis, samples were adjusted to $\mathrm{pH} 9.4$ with $6 \mathrm{M} \mathrm{NaOH}$ in $0.4 \mathrm{M}$ borate buffer and filtered through a $0.2 \mu \mathrm{m}$ Sartorius filter. The hydrolyzed THAA was measured as DFAA by high performance liquid chromatography (HPLC; Waters Chromatographic System) of $o$-phthaldialdehyde-derivatized products (Lindroth \& Mopper 1979).

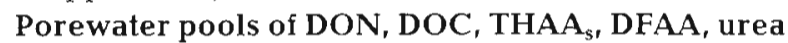
and $\mathrm{NH}_{4}{ }^{+}$. Porewater was obtained by centrifugation $(1000 \times g$ for $10 \mathrm{~min})$ and the supernatant was either filtered through a $0.2 \mu \mathrm{m}$ Sartorius filter (DON, DOC, THAA ${ }_{p w}$ and DFAA samples) or was not filtered $\left(\mathrm{NH}_{4}{ }^{+}\right)$ and frozen for later analysis. Urea samples were obtained by addition of $2 \mathrm{ml}$ artificial seawater to $1 \mathrm{~cm}^{3}$ sediment in order to obtain sufficient sample for analy- 
sis. Immediately after the sediment was mixed with artificial seawater, it was centrifuged for $10 \mathrm{~min}$ at $1000 \times g$ and the supernatant was frozen for later analysis. The urea profile was used as the time zero concentration for the urea turnover calculations, as the urea profile was obtained in parallel to ${ }^{14} \mathrm{C}$-urea incubations. DOC, DON and THAA $A_{p}$ were determined with the depth resolution described above to a total depth of $48.0 \mathrm{~mm}$, whereas DFAA, urea and $\mathrm{NH}_{4}{ }^{+}$were determined to a total depth of $88.5 \mathrm{~mm}$.

Samples for total dissolved nitrogen (TDN = dissolved organic + inorganic nitrogen) and DOC were analyzed as $\mathrm{NO}$ and $\mathrm{CO}_{2}$, respectively, on a modified Antek 7000 system, which in principle was as described in Hansell et al. (1993). An IR detector (Licor LI-6252) for $\mathrm{CO}_{2}$ analysis was placed in series before the chemiluminescence detector for NO. Halogens were removed after the combustion tube by bubbling the gas through a solution of $\mathrm{AgNO}_{3}(5 \% \mathrm{w} / \mathrm{v})$ and $\mathrm{H}_{3} \mathrm{PO}_{4}(10 \% \mathrm{v} / \mathrm{v})$. Water vapor was removed in a water trap $\left(0^{\circ} \mathrm{C}\right)$ and a membrane dryer. The combustion tube (quartz) was maintained at $900^{\circ} \mathrm{C}$. Before analysis, samples were acidified by addition of concentrated $\mathrm{H}_{3} \mathrm{PO}_{4}$ to a final $\mathrm{pH}$ of 1 and bubbled with ultra-pure $\mathrm{N}_{2}$ for $10 \mathrm{~min}$ in order to remove inorganic carbon compounds. The volume of sample analyzed was $50 \mu$ and the concentrations of DOC and TDN were calculated from a 5 point calibration curve made on Tris-buffer.

THAA $_{\text {pw }}$ was determined in a similar manner as THAA $_{5}$ except that $\sim 12 \mathrm{~N} \mathrm{HCl}$ was added to the porewater in a $1: 1 \mathrm{v} / \mathrm{v}$ ratio.

The concentration of DFAA was determined by high-performance liquid chromatography as described above.

Urea was determined by the diacetyl monoxime method described in Price \& Harrison (1987) and $\mathrm{NH}_{4}{ }^{+}$ by the salicylate-hypochlorite method described in Bower \& Holm-Hansen (1980).

The diffusive flux of DON, DOC and $\mathrm{NH}_{4}{ }^{+}$were calculated by Fick's first law of diffusion after the principle described in Ullman \& Aller (1982). The diffusion coefficients for DON and DOC were from Blackburn \& Blackburn (1993) and the diffusion coefficient for $\mathrm{NH}_{4}{ }^{+}$ was from Li \& Gregory (1974).

Urea and DFAA turnover. The urea turnover rates were in principle measured by the tracer method described in Lund \& Blackburn (1989) with the following modifications: from each sediment depth $1 \mathrm{~cm}^{3}$ of homogenized sediment was injected with $2 \mu \mathrm{l}{ }^{14} \mathrm{C}$-urea (1.67 $\mathrm{nCi} \mu \mathrm{l}^{-1}, 56 \mathrm{nCi} \mathrm{nmol}{ }^{-1}$; Amersham) in a $\mathrm{N}_{2}$ flushed exetainer and incubated in a time course 10.0 , 0.5 and $1.0 \mathrm{~h}$ ). Biological activity was stopped and the produced ${ }^{14} \mathrm{CO}_{2}$ was fixed by addition of $2 \mathrm{ml} \mathrm{NaOH}$ $(2.5 \% \mathrm{w} / \mathrm{v})$ and the sediment-NaOH mixture was frozen for later processing for ${ }^{14} \mathrm{C}$ activity.
Amino acid turnover was measured for the 2 amino acids alanine and glutamate at every second depth described in the sampling section. Incubation was performed as follows: (1) $10 \mu{ }^{14} \mathrm{C}$-[U]-amino acid tracer was injected into $0.8 \mathrm{~cm}^{3}$ sediment in a $\mathrm{N}_{2}$-flushed exetainer $\left(0.95 \mathrm{nCi} \mathrm{ll}^{-1}, 155 \mathrm{nCi} \mathrm{nmol}^{-1}\right.$ alanine; $1.72 \mathrm{nCi}$ $\mathrm{Hl}^{-1}, 266 \mathrm{nCi} \mathrm{nmol}^{-1}$ glutamate; Amersham) and incubated in a time course $(0.0,1.0$ and $2.0 \mathrm{~h}$ for alanine and $0.0,3.0$ and $11.0 \mathrm{~h}$ for glutamate); (2) turnover activity was stopped by addition of $1 \mathrm{ml} 2.5 \%(\mathrm{w} / \mathrm{v})$ $\mathrm{NaOH}$; and (3) the sediment- $\mathrm{NaOH}$ suspension was thoroughly mixed and frozen for later analysis.

${ }^{14} \mathrm{C}$-urea, ${ }^{14} \mathrm{C}$-alanine and ${ }^{14} \mathrm{C}$-glutamate were added in trace amounts and the final concentrations were always $<10 \%$ of the respective ambient pools.

Radioactivity was counted in a Packard 2200 CA TriCarb Liquid Scintillation analyzer. The urea turnover rate was calculated by means of the steady state Model II described in Lund \& Blackburn (1989) and the turnover rate of total DFAA was calculated as the average turnover rate constant of alanine and glutamate times the porewater pool of DFAA. Turnover rate constants of alanine and glutamate, in the sediment zones that were not measured, were obtained from linear extrapolation of the respective turnover rate constants in sediment zones above and below. These calculated turnover rate constants were used to obtain the depthintegrated turnover rates. As the alanine and glutamate turnover rate constants were not measured in the 58.5-88.5 $\mathrm{mm}$ zone, it was assumed that the turnover rate constants in the $48.0-58.5 \mathrm{~mm}$ zone were representative for the underlying zone.

Sediment carbon oxidation. The $\mathrm{SCO}_{2}$ efflux from the sediment to the water column was used as an integrated measure of sediment carbon oxidation. The $\Sigma \mathrm{CO}_{2}$ efflux was measured in 5 cores $(3.6 \mathrm{~cm}$ i.d.). The sediment cores were overlaid with bottom water from the sampling location and were 'sealed' with a glass petri dish without the introduction of air bubbles. The water phase was agitated with a magnet, using an incubation system similar to that described in Blackburn et al. (1988). The 5 cores were incubated in the dark at the in situ temperature for $0.7,2.1,2.1,3.8$ and $3.8 \mathrm{~h}$, respectively. The concentration of $\Sigma \mathrm{CO}_{2}$ was determined by flow injection analysis (Hall \& Aller 1992)

\section{RESULTS}

\section{Sediment characteristics}

Microscopical examination of the sediment surface revealed that the benthic primary producers were dominated by diatoms and cyanobacteria and there 
Table 1. Distribution of $\mathrm{Pb}-210$ total, $\mathrm{Pb}-210$ supported $\left(\mathrm{Pb}-210_{\text {sup }}\right)$ and Cs-137 with sediment depth $(n=3)$

\begin{tabular}{|lrrrrrr|}
\hline $\begin{array}{l}\text { Depth } \\
(\mathrm{mm})\end{array}$ & $\begin{array}{c}\text { Pb-210 } \\
\text { total } \\
\left(\mathrm{Bq} \mathrm{kg}^{-1}\right)\end{array}$ & $\begin{array}{c}\text { SD } \\
(\% \text { of } \\
\text { mean })\end{array}$ & $\begin{array}{r}\text { Pb-210 } \\
\left(\mathrm{Bq} \mathrm{kg}^{-1}\right)\end{array}$ & $\begin{array}{c}\text { SD } \\
(\% \text { of } \\
\text { mean })\end{array}$ & $\begin{array}{c}\mathrm{Cs}-137 \\
(\mathrm{~Bq} \mathrm{~kg}\end{array}$ & $\begin{array}{c}\text { SD } \\
(\% \text { of } \\
\text { mean })\end{array}$ \\
\hline $0.0-1.5$ & 20.0 & 12.8 & 20.2 & 7.2 & 15.4 & 12.0 \\
$1.5-3.0$ & 8.9 & 17.3 & 14.3 & 8.2 & 14.1 & 12.9 \\
$3.0-4.5$ & 6.2 & 12.5 & 17.9 & 7.1 & 16.9 & 9.9 \\
$4.5-6.0$ & 20.7 & 20.5 & 18.0 & 7.7 & 14.5 & 12.9 \\
$6.0-7.5$ & 11.1 & 13.7 & 13.5 & 8.5 & 16.5 & 10.6 \\
$7.5-12.0$ & 6.2 & 13.6 & 12.5 & 8.6 & 14.0 & 12.3 \\
$12.0-16.5$ & 16.6 & 13.3 & 10.4 & 9.8 & 11.5 & 16.1 \\
$16.5-27.0$ & 14.2 & 16.7 & 8.2 & 11.3 & 11.0 & 17.2 \\
$27.0-37.5$ & 10.1 & 15.4 & 5.9 & 12.8 & 11.4 & 14.9 \\
$37.5-48.0$ & 0.9 & 13.1 & 11.8 & 7.5 & 11.0 & 13.5 \\
$48.0-58.5$ & 11.7 & 16.1 & 6.2 & 12.1 & 11.5 & 14.8 \\
$58.5-88.5$ & 11.8 & 15.9 & 12.6 & 8.5 & 5.5 & 37.4 \\
\hline
\end{tabular}

There was a decrease in chlorophyll a (chl a) and total pigment with sediment depth and their contents were reduced to 34 and $30 \%$, respectively, in the $12.0-16.5 \mathrm{~mm}$ depth zone compared to the contents in the sediment surface (Fig. 1). The total pigment content was the sum of the chl a peak and a peak with a retention time of 10.28 min (results not shown).

There was an almost linear decrease in the total contents of POC and PON within the upper $-14 \mathrm{~mm}$ of the sediment from 566 and $72 \mu \mathrm{mol} \mathrm{cm} \mathrm{cm}^{-3}$, respectively, in the surface to

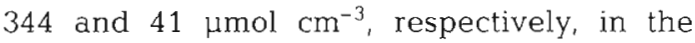
12.0-16.5 mm zone; the POC and PON contents fluctuated somewhat below this zone (Fig. 2a, b). There was a slight increase in the contents of THAA Tarbon $_{s}$ (THAA $A_{s}-\mathrm{C}$ ) and were a few of the pelagic diatom Nitzschia longissima. Visual inspection of sediment cores showed that the benthic macrofauna was dominated by small polychaetes. SCUBA diving observations of the sediment surface showed that Arenicola marina was present.

Table 1 gives the data of total $\mathrm{Pb}-210, \mathrm{~Pb}-210_{\text {sup }}$ and Cs-137 versus sediment depth. The total $\mathrm{Pb}-210$ and $\mathrm{Pb}-210_{\text {sup }}$ activities were of similar magnitude and were all $<20.7 \mathrm{~Bq} \mathrm{~kg} \mathrm{~kg}^{-1}$. Therefore, it was not possible to calculate unsupported $\mathrm{Pb}-210$ values. Standard deviations for the activity determinations varied between 7.1 and $20.5 \%$ of the means. The activity of Cs-137 varied between 14.0 and $16.9 \mathrm{~Bq} \mathrm{~kg}^{-1}$ within the upper $\sim 9 \mathrm{~mm}$ of the sediment and decreased to $11.5 \mathrm{~Bq} \mathrm{~kg}^{-1}$ in the $12.0-16.5 \mathrm{~mm}$ zone. The Cs-137 activity remained at 11.0 to $11.5 \mathrm{~Bq} \mathrm{~kg}{ }^{-1}$ throughout most of the underlying sediment, but decreased further to $5.5 \mathrm{~Bq}$ $\mathrm{kg}^{-1}$ in the 58.5-88.5 $\mathrm{mm}$ zone (Table 1).

\section{Pigments, $\mu \mathrm{g} \mathrm{cm}^{-3}$}

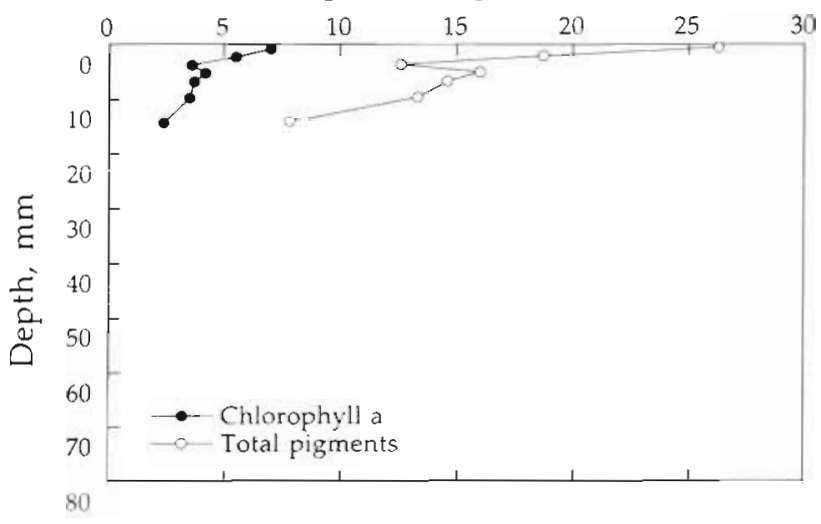

Fig. 1. Distribution of chlorophyll $a$ and total pigment content with depth
THAA $A_{5}$ nitrogen $\left(\mathrm{THAA}_{\mathrm{s}}-\mathrm{N}\right.$ ) within the upper few $\mathrm{mm}$ of the sediment, where THAA $A_{s}-\mathrm{C}$ and $\mathrm{THAA}_{s}-\mathrm{N}$

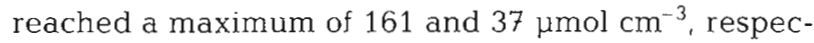
tively, in the $3.0-4.5 \mathrm{~mm}$ zone (Fig. 2a, b). THAA remained almost constant at sediment depths exceeding $7.5 \mathrm{~mm}$. The molar composition of $\mathrm{THAA}_{\mathrm{s}}$ did not show any consistent trend with sediment depth (Fig. 3). Glycine was the most abundant amino acid residue of $\mathrm{THAA}_{\mathrm{St}}$ followed by aspartate and glutamate (Fig. 3). Unidentified amino acids (named 'Others' on Fig. 3) only accounted for 5 to $6 \%$ of total THAA $_{s}$.

The integrated $\left(\sum 0.0-88.5 \mathrm{~mm}\right)$ pools of POC, PON, THAA $_{\mathrm{s}}-\mathrm{C}$, THAA $-\mathrm{N}$ and the unknown POC and PON pools are shown in Table 2. THAAs accounted for $24 \%$ of the POC pool and $53 \%$ of the PON pool, whereas the remaining pools of particulate organic matter (POM) were not identified. total POM pool, the THAA $\mathrm{A}_{5}$ pool and the unidentified POM pool are shown in Fig. 2c. The average $\mathrm{C} / \mathrm{N}$ ratio of the total POM pool increased with depth, from 7.8 in the sediment surface to 11.5 in the $58.5-$ $88.5 \mathrm{~mm}$ depth zone, whereas the $\mathrm{C} / \mathrm{N}$ ratio of the THAA $_{S}$ pool remained constant with depth. The average $\mathrm{C} / \mathrm{N}$ ratio in the unidentified POM pool varied between 11.1 and 15.7 .

\section{Porewater contents of DOC, DON, THAA ${ }_{p w}-C$, THAA ${ }_{p w}-\mathrm{N}$, DFAA-C, DFAA-N, urea and $\mathrm{NH}_{4}{ }^{+}$}

Fig. 4a, b gives the profiles of the different dissolved carbon and nitrogen pools that were measured. THAA $A_{\text {pw }}$ was the most important of the identified DOM components and accounted for $9.2 \%$ of the integrated ( $(20.0-48.0 \mathrm{~mm}$ ) DOC pool and $26.8 \%$ of the DON pool
Profiles of the average $\mathrm{C} / \mathrm{N}$ ratio $\left(\mathrm{mol} \mathrm{mol}{ }^{-1}\right)$ in the 
POC, $\mu \mathrm{mol} \mathrm{cm}^{-3}$

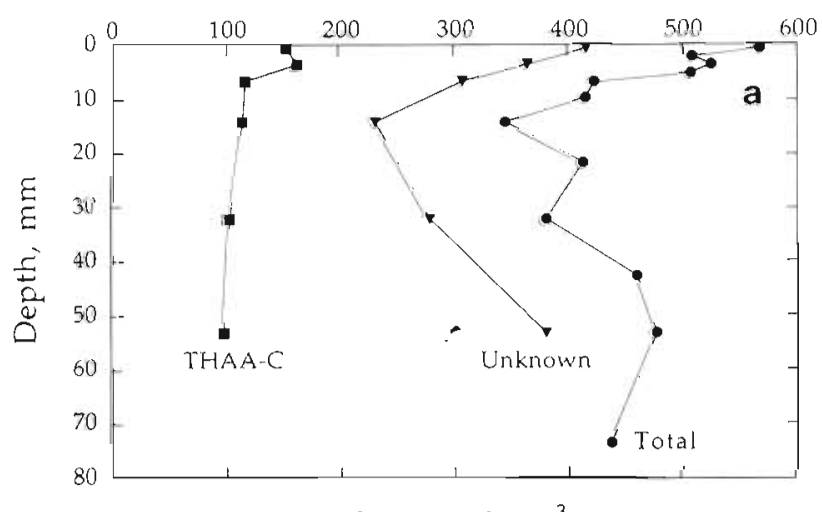

PON, $\mu \mathrm{mol} \mathrm{cm} \mathrm{cm}^{-3}$

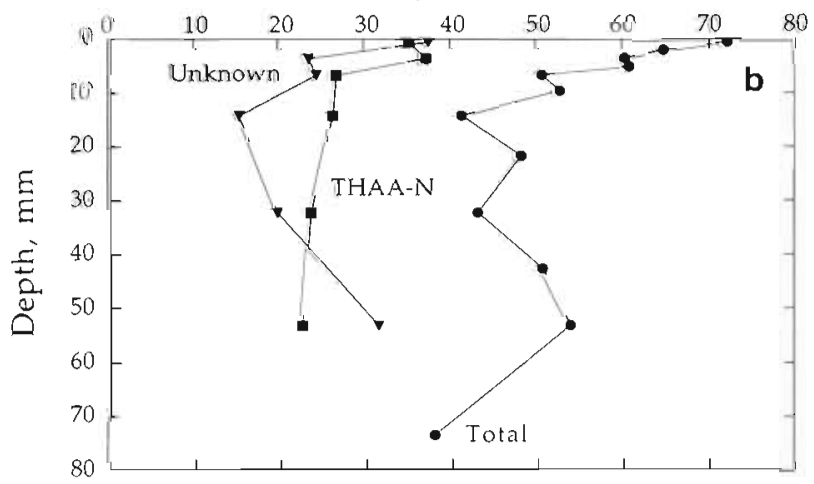

$\mathrm{C} / \mathrm{N}, \mathrm{mol} \mathrm{mol}{ }^{-1}$

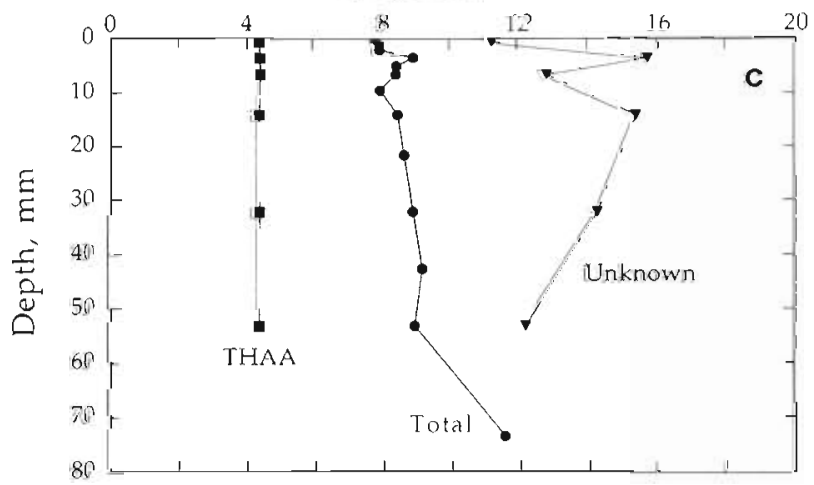

Fig. 2. Vertical distribution of sediment (a) POC, (b) PON and (c) molar C/N ratios

(Table 2). Glutamate was the dominating protein amino acid in the THAA pool followed by glycine and aspartate (Fig. 3). Unidentified amines (named 'Others' on Fig. 3) comprised up to $19.4 \%$ of the THAA $_{\text {pw }}$ pool.

Urea and DFAA were of minor importance for the total pools of DOC and DON, as the integrated $(\Sigma 0-48.0 \mathrm{~mm})$ urea and DFAA pools only accounted for 0.1 and $3.9 \%$ of the DOC pool, respectively, and 1.8 and $10.1 \%$ of the DON pool, respectively (Table 2 ). Glutamate was the dominating protein amino acid in
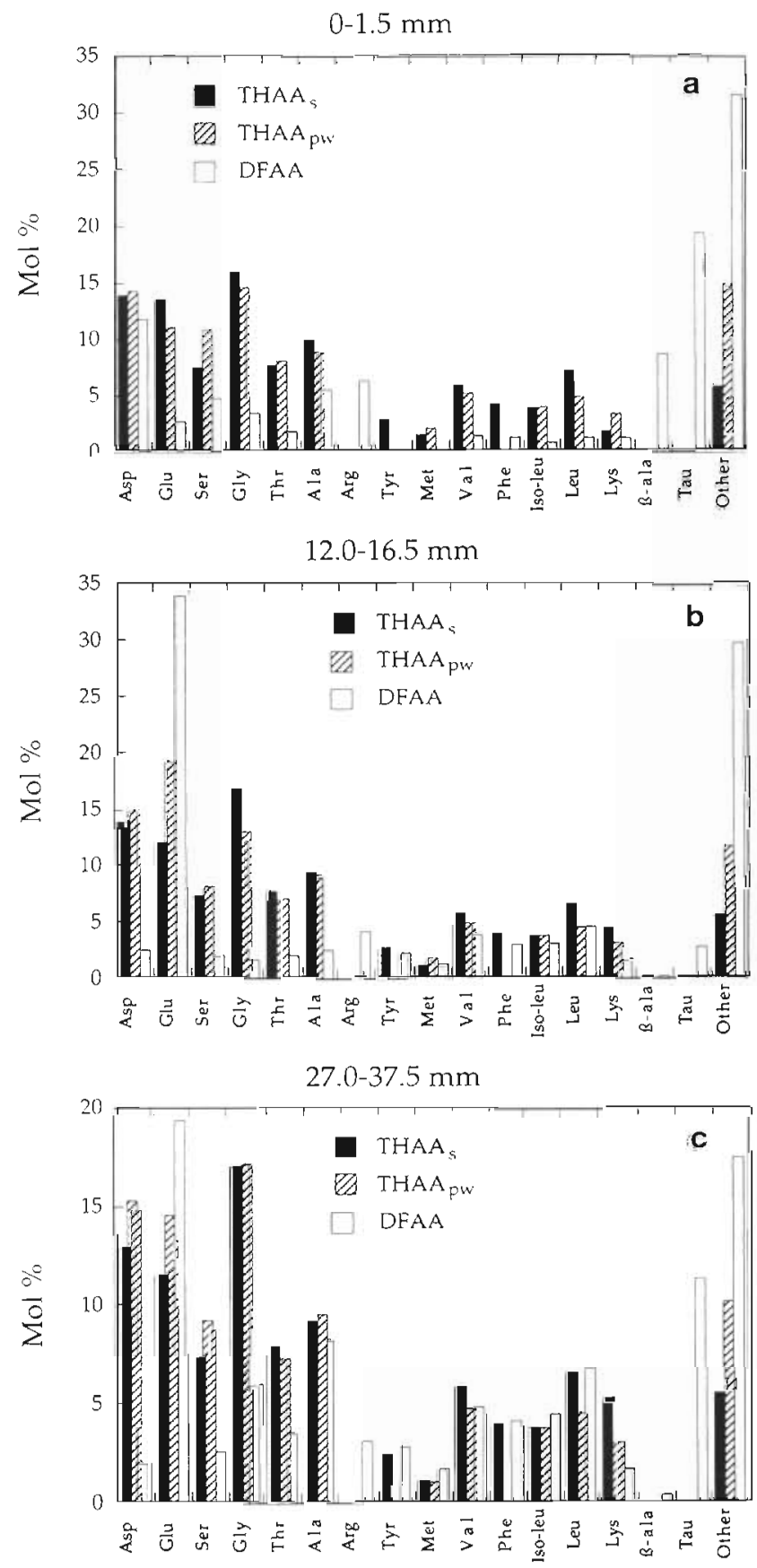

Fig. 3. Mol percentages of individual amino acids in sediment THAA (THAA $)$ ), porewater THAA (THAA (Tw) and DFAA in 3 zones of the sediment. Values from (a) the surface $0-1.5 \mathrm{~mm}$, (b) the $12.0-16.5 \mathrm{~mm}$ zone and (c) the $27.0-37.5 \mathrm{~mm}$ zone

the DFAA pool, except in the upper $1.5 \mathrm{~mm}$ of the sediment, followed by glycine and alanine (Fig. 3). The non-protein amino acid taurine and unidentified others accounted for $2.8-19.3 \%$ and up to $36.2 \%(1.5-4.5 \mathrm{~mm}$ zone, data not shown), respectively, of the DFAA pool in the sediment. 
Dissolved organic carbon, $\mathrm{nmol} \mathrm{cm}^{-3}$

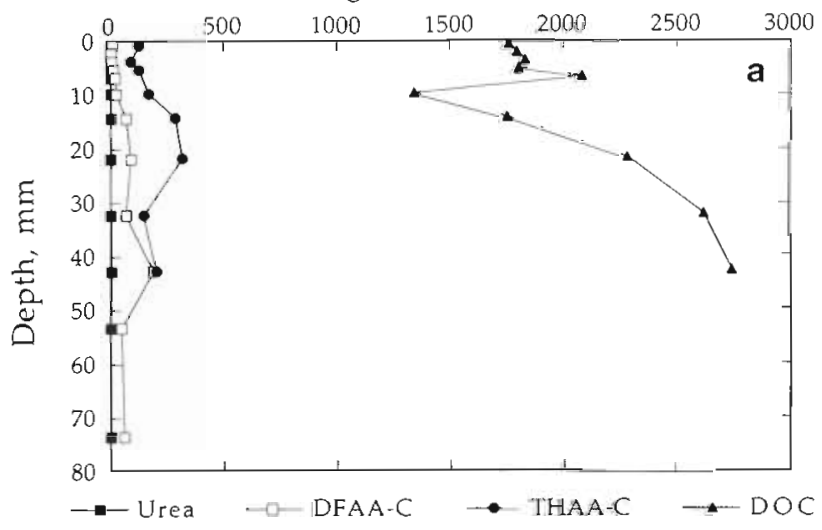

Dissolved nitrogen, nmol- $\mathrm{N} \mathrm{cm}^{-3}$

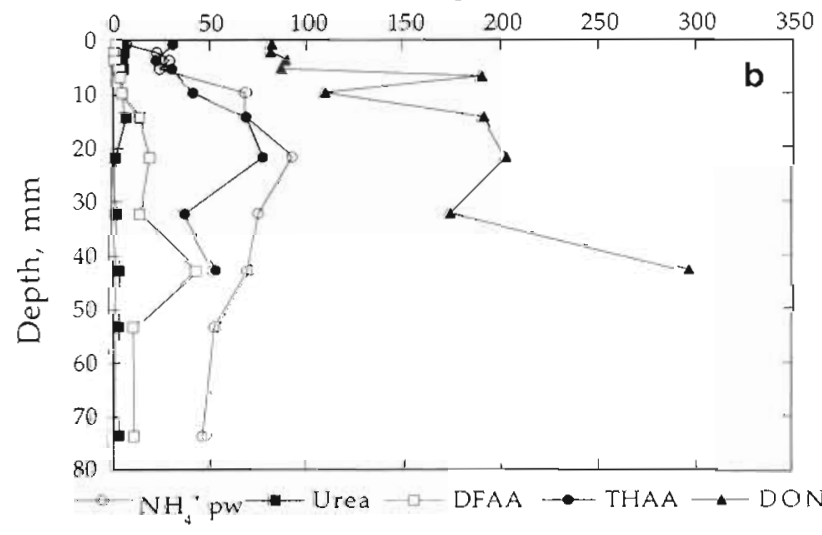

$\mathrm{C} / \mathrm{N}$ ratio in dissolved organic matter, $\mathrm{mol} \mathrm{mol} \mathrm{m}^{-1}$

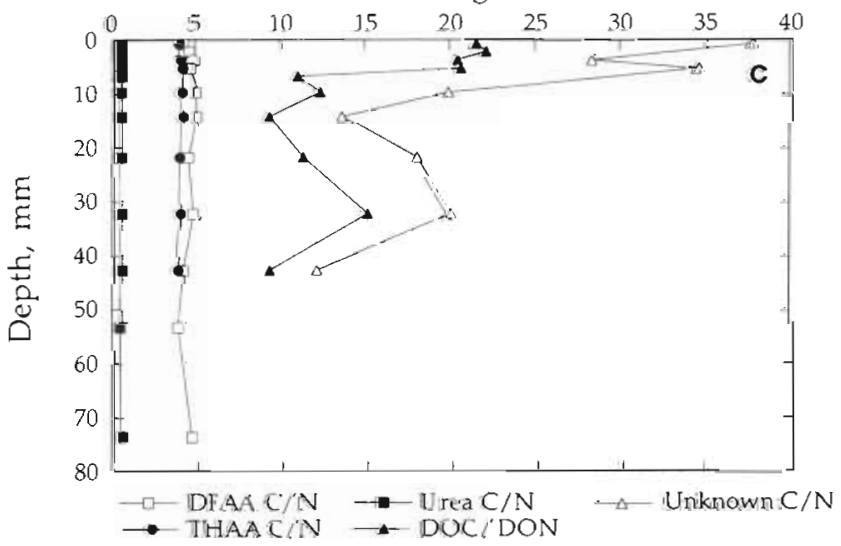

Fig. 4. Vertical distribution of (a) DOC, (b) DON and (c) the molar $\mathrm{C} / \mathrm{N}$ ratio of dissolved organic matter

sible for organic matter mixing into the sediment as (1) taurine was distributed throughout the sediment $(0.0-88.5 \mathrm{~mm})$ and (2) $\mathrm{Pb}-210$ and Cs-137 actitivies were low and variable throughout the sediment, which prevented dating of the sediment. Taurine is usually found in invertebrate tissue (Henrichs \& Farrington 1987, Hansen \& Blackburn 1995) and may have been
Turnover rate, nmol $\mathrm{cm}^{-3} \mathrm{~d}^{-1}$

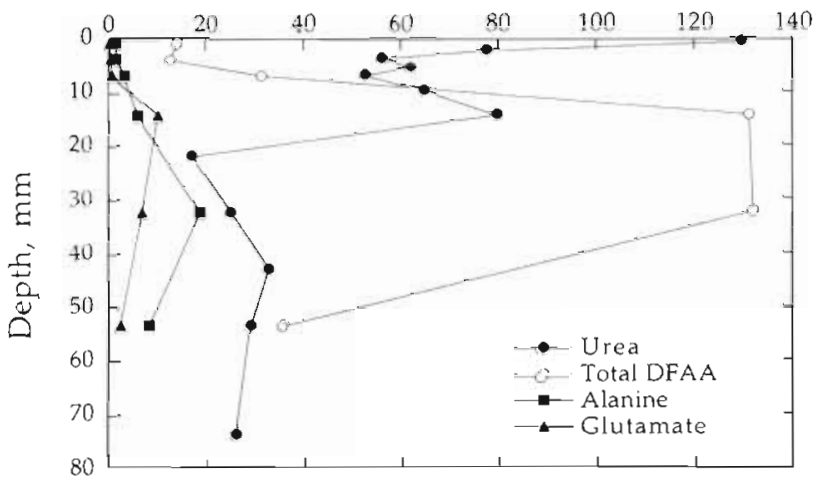

Fig. 5. Vertical distribution of turnover rates of urea, alanine, glutamate and total DFAA

excreted to the surrounding sediment. The presence of taurine throughout the sediment indicated that it was supplied all through the sediment, as sulfate reducing bacteria can use taurine as a substrate (Hansen et al. 1993) and thus limit the distance of taurine diffusion. Arenicola marina was observed at the sampling locality during a SCUBA diving inspection of the sediment surface. As A. marina is able to mix the upper 20 to $30 \mathrm{~cm}$ of a sediment (Cadée 1976), it may have been responsible for the observed sediment mixing. In accordance with the present study, Pedersen et al. (1995) were not able to identify the peak in nuclear weapon testing in 1963 nor the 1987 Chernobyl accident in a sediment disturbed by drifting sea-ice. The most likely explanation for the lack of typical profiles of $\mathrm{Pb}-210$ and $\mathrm{Cs}-137$ activity in the present study was bioturbation activity. Alternatively, mixing could have been due to current or waves, but we find this latter explanation less likely, as the sediment was composed of silty sand. However, Christiansen et al. (1981) found that even though the area with silty sand sediment in which we sampled could be considered as an area of general deposition, there was no doubt that storm events could bring bottom sediment into suspension.

\section{Composition of sediment POM}

THAA $_{S}-\mathrm{C}$ accounted for 20 to $33 \%$ of POC $(24 \%$ of ₹0.0-88.5 mm POC) and THAA $-\mathrm{N}$ made up 42 to $63 \%$ of PON (53\% of $\sum 0-88.5 \mathrm{~mm}$ PON). For comparison, Henrichs \& Farrington (1987) found that THAA made up 24 to $38 \%$ of sediment PON in surface sediments of Buzzards Bay, USA, which were extensively bioturbated. Similarly to the present study, Henrichs \& Farrington (1987) did not find any detectable changes in THAA composition, as a result of decomposition, with depth. The homogenous molar composition of THAA 
with depth was possibly due to macrofauna mixing organic matter into the sediment with a resultant relatively uniform age of the organic matter that was turned over. Contrary to the present study, Burdige \& Martens (1990) observed a decrease in the mole percentages of glutamate and alanine with depth, while that of glycine increased. The sediment in the Burdige \& Martens (1990) study was not bioturbated and they explained the changes in the molar composition of THAA as a selective utilization of glutamate and alanine and a selective preservation of glycine.

\section{Composition of sediment DOM}

The most important DOM constituent was THAA Tw. $_{\text {p }}$ which accounted for $9.2 \%$ of DOC and $26.8 \%$ of DON on an area basis ( $\Sigma 0-48.0 \mathrm{~mm})$. Inspection of the molar amino acid composition in THAA THAA $_{\text {sw }}$ and DFAA revealed interesting differences in the amino acid composition. There was an increase in the mole percentage of non-protein amino acids ( $\beta$-alanine + taurine + unidentified others, see Fig. 3) from THAAs

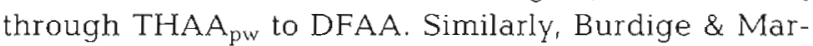
tens (1990) found higher mole percentages of many non-protein amino acids in DFAA relative to that observed in sediment THAA. As the sediment in the Burdige \& Martens (1990) study was not bioturbated, they suggested that the non-protein amino acids were produced as transient intermediates in the mineralization of certain protein amino acids and other biologically produced nitrogen compounds. Similarly, we suggest that the unidentified 'Others' may have been transient intermediates as suggested above.

The present investigation identified $13.2 \%$ of the DOC pool and $38.8 \%$ of the DON pool as THAA $_{p w}+$ DFAA + urea ( $\Sigma 0-48.0 \mathrm{~mm}$ ) of which DFAA and urea only accounted for a minor fraction. The average $\mathrm{C} / \mathrm{N}$ ratio of the unidentified DOM pool, which varied between 12.0 and $37.7 \mathrm{~mol} \mathrm{~mol}^{-1}$, was far too high to represent a single dissolved-nitrogen-containing organic molecule. Not surprisingly, this implies that the unidentified DOM pool was a composite pool that contained dissolved organic molecules without nitrogen together wiik niilogen-containing organic molecules Among pure-carbon-containing DOM molecules that may have been important in the present study were saccharides, fatty acids and alcohols. Fatty acids and alcohols are intermediates in anaerobic mineralization and they are transferred between the different physiological types of organisms of the anaerobic detritus food chains (Jørgensen 1983). Similarly, the nitrogencontaining dissolved organic molecules, which were not identified, were likely to have been products of hydrolysis and intermediates in anaerobic organic matter degradation. RNA may have been of particular importance, as this organic molecule is the second most important nitrogen-containing organic molecule in living cells. A microalgal input to the sediment of $2.9 \mathrm{~g} \mathrm{C} \mathrm{m}^{-2}$, equivalent to $1 \%$ of annual primary production and typical for shallow Danish waters, would roughly supply the sediment with $5 \mathrm{mmol}$ RNA-N m${ }^{-2}$ This calculation is based on the RNA content in Euglena sp. cells (Smillie \& Kratkov 1960), an algal carbon content of $10 \%$ of algal dry weight and an average molar nitrogen content in RNA of 3. Comparing the potential RNA-N input from microalgal cells with the unidentified DON pool (5.7 mmol $\mathrm{N} \mathrm{m}^{-2}, \Sigma 0-48.0 \mathrm{~mm}$ ), it is likely that RNA is an important component of the DON pool after a phytoplankton sedimentation event and/or during decay of benthic microalgae.

\section{Turnover of urea and DFAA}

The depth distribution of urea, glutamate, alanine and total DFAA turnover activity showed that maximum urea turnover activity was spatially separated from maximum DFAA turnover activity. This indicates that the turnover of urea and DFAA were independent processes, which both gave rise to $\mathrm{NH}_{4}{ }^{+}$production. Therkildsen et al. (1996) showed that urea production and turnover were stimulated after the addition of AMP (adenosine 5'-monophosphate). CMP (cytidine 5'-monophosphate) and RNA (16S ribosomal RNA) to an anoxic marine sediment, whereas the addition of protein only stimulated $\mathrm{NH}_{4}{ }^{+}$ production. In addition, Therkildsen et al. (1996) suggested that intracellular nucleic acids, especially RNA, may also contribute to urea production together with the turnover of extracellular nucleic acids taken up by the bacterial cells. Based on the above information and the estimated potential input of RNA to the sediment from microalgal cells, it is probable that urea production in the present investigation was mainly due to RNA degradation. In parallel to urea production from RNA, there is also deamination that leads directly to $\mathrm{NH}_{4}{ }^{*}$ production (Therkildsen et al. 1996). Further, it has been shown that the initial step in the degradation of both adenine and rytosine is deamination (Vogels \& Van der Drift 1976, Busse et al. 1984, Gottschalk 1986, Kaspari \& Busse 1986). However, it is not possible to predict the ratio between urea production and direct $\mathrm{NH}_{4}{ }^{+}$production from RNA degradation, as this ratio is dependent on the functional degradation pathway. Previous investigations have shown that up to $80 \%$ of added AMP-N can be degraded through urea (Busse et al. 1984, Kaspari \& Busse 1986) and Therkildsen et al. (1996) showed that urea turnover accounted for a significant 

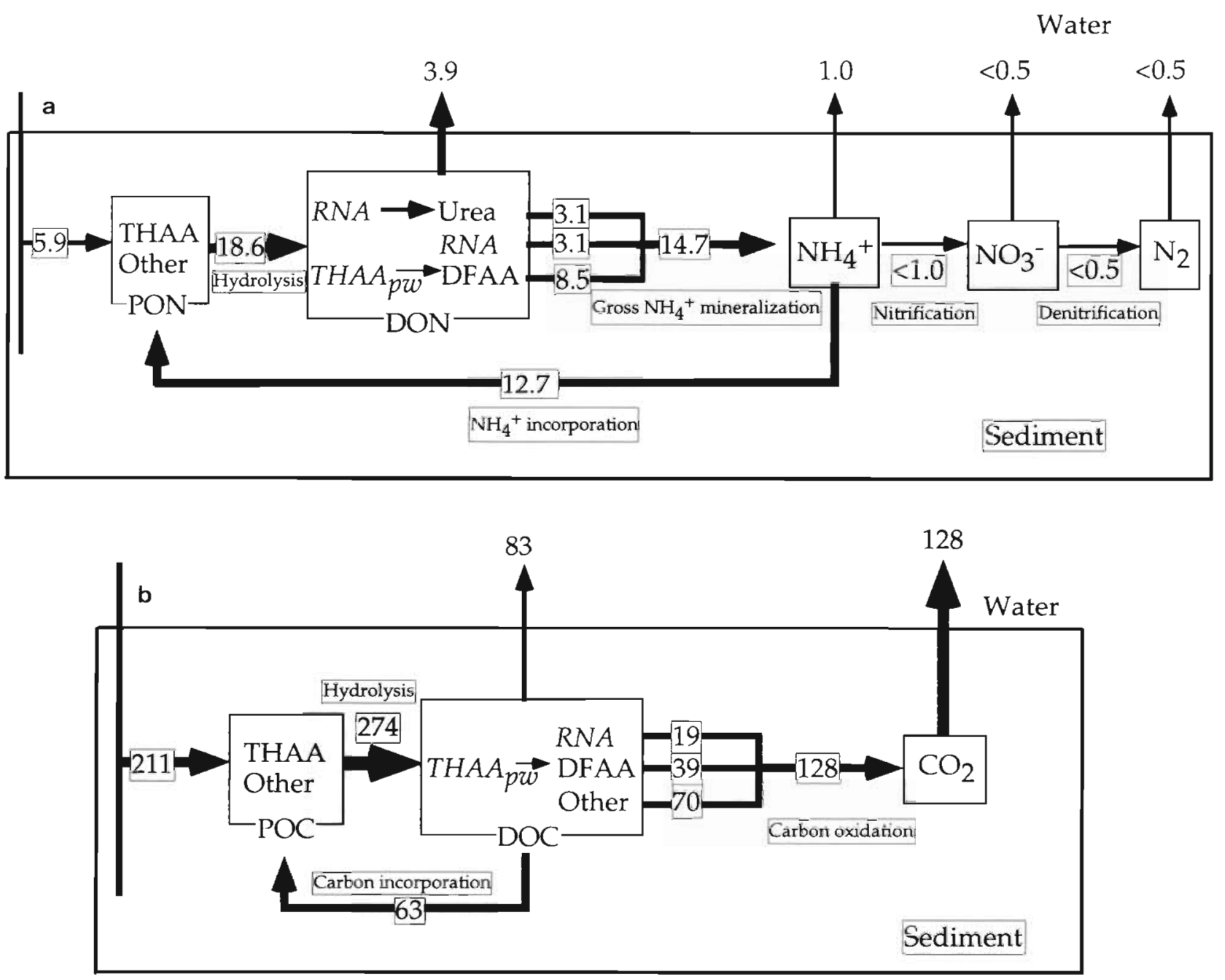

Fig. 6. (a) Nitrogen budget and (b) carbon budget for Knebel Vig sediment. Rates are given in mmol $\mathrm{m}^{-2} \mathrm{~d}^{-1}$. See text for further information

fraction of net $\mathrm{NH}_{4}{ }^{+}$production in a RNA amended anoxic sediment.

Urea turnover may have been slightly underestimated within the upper $1.5 \mathrm{~mm}$ sediment surface due to the anoxic incubation conditions, as A.-G. U. Jensen, L. S. Hansen \& B. Aa. Lomstein (unpubl.) showed stimulated urea turnover in the presence of oxygen. We did not measure oxygen penetration into the sediment, but it is likely that oxygen was present within the upper $1.5 \mathrm{~mm}$ of the sediment. Further, the turnover of alanine and glutamate may have been overestimated in the upper surface zone of the sediment, due to the anoxic incubation, as oxic conditions have been shown to reduce alanine and glutamate turnover (Jensen et al. unpubl.). The anoxic incubation condition did not, however, affect the area integrated urea, alanine and glutamate turnover rates, as oxygen penetration into the sediment was small compared to the total integration depth $(88.5 \mathrm{~mm})$ of urea, alanine and glutamate turnover activities.

\section{Nitrogen and carbon cycling in the shallow water Knebel Vig sediment: conceptual models}

Further discussion will be related to Fig. 6 and Table 2, in which the area integrated measured and calculated rates can be seen in relation to each other. Integrated $(0.0-88.5 \mathrm{~mm})$ gross $\mathrm{NH}_{4}{ }^{+}$production from the degradation of organic matter was calculated as total DFAA turnover + urea turnover + an assumed direct $\mathrm{NH}_{4}{ }^{+}$production from deamination of RNA (Table 2). The ratio between direct $\mathrm{NH}_{4}{ }^{+}$production and urea-N production from RNA was chosen to be 1 , 
due to the lack of real information on the functional degradation pathway of RNA within the sediment. In addition, it was assumed that RNA was the only major source for urea production (see the discussion above). This assumption allowed estimation of carbon oxidation from other sources than RNA and DFAA. Carbon oxidation from unidentified DOC was $70 \mathrm{mmol} \mathrm{C} \mathrm{m}$ $\mathrm{d}^{-1}$ and accounted for $55 \%$ of total carbon oxidation. We used the $\mathrm{SCO}_{2}$ efflux from the sediment to draw conclusions regarding benthic $C$ oxidation. It is believed that this method approximated benthic $\mathrm{C}$ oxidation, as assimilation of $\mathrm{CO}_{2}$ by chemoautotrophic bacteria could not have altered the $\Sigma \mathrm{CO}_{2}$ efflux significantly. Previous studies in the same area have shown that denitrification of $\mathrm{NO}_{3}^{-}$from nitrification within the sediment was low $<0.02 \mathrm{mmol} \mathrm{N} \mathrm{m}^{-2} \mathrm{~d}^{-1}$; Sloth et al. 1996), which indicated that nitrification was also low. The carbon flow through methane-producing bacteria could probably also be disregarded.

The calculated diffusive efflux of DON from the sediment was high ( $3.9 \mathrm{mmol} \mathrm{N} \mathrm{m}^{-2} \mathrm{~d}^{-1}$ ) compared to the calculated efflux of $\mathrm{NH}_{4}{ }^{+}\left(1.0 \mathrm{mmol} \mathrm{N} \mathrm{m}{ }^{-2} \mathrm{~d}^{-1}\right)$. Blackburn et al. (1996) found similar high rates of DON efflux from the sediment and low rates of $\mathrm{NH}_{4}{ }^{+}$efflux in a study from Svalbard, Norway. They suggested that hydrolysis of organic detritus at the sediment surface would lead to a large diffusional loss of DON to the overlying water. This explanation may also be valid for the present study, except that we do not know to what extent DON effluxed to the overlying water or was assimilated by benthic microalgae.

The calculated efflux of $\mathrm{NH}_{4}{ }^{+}$was low $(1.0 \mathrm{mmol} \mathrm{N}$ $\mathrm{m}^{-2} \mathrm{~d}^{-1}$ ) compared to $\mathrm{NH}_{4}{ }^{+}$mineralization $(14.7 \mathrm{mmol}$ $\mathrm{N} \mathrm{m}^{-2} \mathrm{~d}^{-1}$ ). Values for nitrification and denitrification of 1.0 and $0.5 \mathrm{mmol} \mathrm{N} \mathrm{m}^{-2} \mathrm{~d}^{-1}$, respectively, were chosen, and these values represent maximum values of nitrification and denitrification in shallow Danish sediments with low concentrations of $\mathrm{NO}_{3}{ }^{-}$in the overlying water (Nielsen pers, comm.). The low DIN efflux from the sediment resulted in a very high $\mathrm{C} / \mathrm{N}$ ratio in the efflux products $\left(\Sigma \mathrm{CO}_{2}\right.$ efflux/DIN efflux $\left.>64\right)$. This high ratio implied that the organic matter degraded, on the average, was low in nitrogen. Similar results were obtained by Blackburn et al. (1996). Data from many other studies also suggest high $C / N$ ratios of mineralization (see Blackburn et al. 1996.).

The high rate of gross $\mathrm{NH}_{4}{ }^{+}$mineralization and low rates of DIN efflux demand an explanation on what happened to the remaining $12.7 \mathrm{mmol} \mathrm{N} \mathrm{m}^{-2} \mathrm{~d}^{-1}$. Our proposal is that this $\mathrm{NH}_{4}{ }^{+}$was incorporated into microbial biomass. This suggests that mineralization within the sediment was through a closed cycle of alternate organic nitrogen degradation and resynthesis, driven by carbon oxidation. This explanation is similar to what was suggested by Lomstein et al. (1989) in a study from the northern Bering shelf (USA) sediment. The resultant ratio between the suggested bacterial incorporation (i) and gross $\mathrm{NH}_{4}{ }^{+}$production (d) was 0.86 and thus within the range of previously obtained $i / d$ ratios $(0.33$ to 1.21) from a study on nitrogen cycling in different types of sediment from Danish waters (Blackburn \& Henriksen 1983). Knowledge on the rates of gross $\mathrm{NH}_{4}{ }^{+}$mineralization, $\mathrm{NH}_{4}{ }^{+}$incorporation, $\mathrm{C}$ oxidation and the $\mathrm{C} / \mathrm{N}$ ratio of bacterial cells (mean of $5.0 \mathrm{~mol}$ $\mathrm{mol}^{-1}$; Fagerbakke et al. 1996) were used to calculate the average efficiency of carbon assimilation $(E)$ and the average $\mathrm{C} / \mathrm{N}$ ratio of organic substrate degraded $\left(1 / N_{s}\right)$ according to Blackburn $(1980) ; N_{s}$ was the $N / C$ molar ratio of substrate. Finally, $E$ was used to calculate total carbon degradation $\left(C_{\mathrm{d}}\right)$ and carbon incorporation into bacterial cells $\left(C_{1}\right)$ by the formulate described in Blackburn (1983). The efficiency of carbon incorporation was 0.33 and within the range of previously obtained data on carbon incorporation efficiencies (0.06 to 0.49) obtained from Danish sediments (Blackburn \& Henriksen 1983). The average $\mathrm{C} / \mathrm{N}$ ratio of organic matter degraded was 13.1, supporting the evidence from the $\mathrm{C} / \mathrm{N}$ ratio in efflux products that the organic matter degraded on average was low in nitrogen. This information suggests unexpected characteristics of $\mathrm{C}$ and $\mathrm{N}$ mineralization. Despite the fact that the average $\mathrm{C} / \mathrm{N}$ ratio of sediment $\mathrm{POM}$ was relatively low ( 7.8 to $11.3 \mathrm{~mol} \mathrm{~mol}^{-1}$ ) and $\mathrm{THAA}_{5}-\mathrm{N}$ accounted for $53 \%$ of PON, there were high rates of $\mathrm{NH}_{4}{ }^{+}$incorporation into bacterial cell and a high $\mathrm{C} / \mathrm{N}$ ratio in efflux products. As suggested by Blackburn (1983), the implication of this is that bacteria synthesize cell material as proteins and nucleic acids with a higher nitrogen content than that in the organic matter, which they degrade. This further implied that even though THAAs accounted for a large fraction of the POM pool and the average $\mathrm{C} / \mathrm{N}$ ratio of $\mathrm{THAA}_{\mathrm{S}}$ was 4.4 , only part of this pool was available for bacterial degradation. Total carbon degradation $\left(C_{d}\right)$ amounted to $191 \mathrm{mmol} \mathrm{C} \mathrm{m}^{-2} \mathrm{~d}^{-1}$ and carbon incorporation into bacterial cells $\left(C_{i}\right)$ was $63 \mathrm{mmol} \mathrm{C} \mathrm{m}^{-2} \mathrm{~d}^{-1}$ Total POC and PON hydrolysis could be calculated as DOC efflux $+C_{d}$ and DON

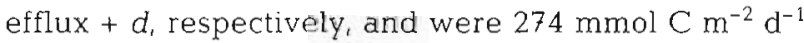
and $18.6 \mathrm{mmol} \mathrm{N} \mathrm{m}^{-2} \mathrm{~d}^{-1}$. The POM input to the sediment or the decrease in sediment POM that was necessary to fuel carbon and nitrogen degradation could thus be calculated to have been $211 \mathrm{mmol} \mathrm{C} \mathrm{m}^{-2} \mathrm{~d}^{-1}$ and $5.9 \mathrm{mmol} \mathrm{N} \mathrm{m}^{-2} \mathrm{~d}^{-1}$, respectively (Fig. 6).

The calculations made to construct the conceptual models on $\mathrm{C}$ and $\mathrm{N}$ cycling were based on 2 basic assumptions: (1) urea- $N$ turnover accounted for $50 \%$ of all $\mathrm{NH}_{4}{ }^{+}$production from RNA-degradation and (2) the 0.0-88.5 $\mathrm{mm}$ integrated gross $\mathrm{NH}_{4}{ }^{*}$ mineralization comprised all $\mathrm{N}$ mineralization and could thus be directly compared to $\mathrm{C}$ mineralization. Two alternative 
$N$ loss by efflux and burial associated with a low efflux of inorganic- $\mathrm{N}$ and with nitrate assimilation in Arctic sediments (Svalbard). Mar Ecol Prog Ser 1.41:283-293

Blackburn TH, Henriksen K (1983) Nitrogen cycling in different types of sediment from Danish waters. Limnol Oceanogr 28:477-493

Blackburn TH, Lund BAa, Krom MD (1988) C-and N-mineralization in the sediments of earthen marine fishponds. Mar Ecol Prog Ser 44:221-227

Bower CE, Holm-Hansen T (1980) A salicylate-hypochlorite method for determining ammonia in seawater. Can J Fish Aquat Sci 37:794-798

Burdige DJ, Martens CS (1990) Biogeochemical cycling in an organic-rich coastal marine basin: 11. The sedimentary cycling of dissolved, free amino acids. Geochim Cosmochim Acta 54:3033-3052

Busse W, Kaspari H, Klemme JH (1984) Urea: an intermediate of aerobic and anaerobic purine degradation in Rhodopseudomonas capsulata. FEMS Microbiol Lett 25:33-36

Cadée GC: (1976) Sediment reworking by Arenicola marina on tidal flats in the Dutch Wadden Sea. Neth J Sea Res 10: $440-460$

Christensen D, Blackburn TH (1980) Turnover of tracer $\left({ }^{14} \mathrm{C}\right.$, ${ }^{3} \mathrm{H}$ labeled) alanine in inshore marine sediments. Mar Biol 58:97-103

Christiansen C, Christoffersen H, Schultz KE (1981) Hydrography, sediments and sedimentation in a low-energy embayment, Knebel Vig. Denmark. Geografiska Annaler 63.A:95-103

Fagerbakke KM, Heldal M, Norland S (1996) Content of carbon, nitrogen, sulfur and phosphorus in native aquatic and cultured bacteria. Aquat Microb Ecol 10:15-27

Gottschalk G (1986) Bacterial metabolism. Springer-Verlag. New York

Hall POJ, Aller RC (1992) Rapid, small-volume, flow injection analysis for $\mathrm{CO}_{2}$ and $\mathrm{NH}_{4}{ }^{+}$in marine and freshwater. Limnol Oceanogr 37:1113-1119

Hansell DA, Williams PM, Ward BB (1993) Measurements of DOC and DON in the Southern California Bight using oxidation by high temperature combustion. Deep Sea Res 40: $219-234$

Hansen LS, Blackburn TH (1995) Amino acid degradation by sulfate-reducing bacteria: evaluation of four methods. Limnol Oceanogr 40:502-510

Hansen LS, Holmer M, Blackburn TH (1993) Mineralization of organic nitrogen and carbon (fish food) added to anoxic sediment microcosms: role of sulfate reduction. Mar Ecol Prog Ser 102:199-204

Henrichs SM, Farrington JW (1984) Peru upwelling region sediments near $15^{\circ} \mathrm{S} .1$. Remineralization and accumulation of organic matter. Limnol Oceanogr 29:1-19

Henrichs SM, Farrington JW (1987) Early diagenesis of amino acids and organic matter in two coastal marine sediments Geochim Cosmochim Acta 51:1-15

Hurley JP (1988) Analysis of aquatic pigments by high performance liquid chromatography. J Anal Purif June·12-16

Editorial responsibility: Tom Fenchel,

Helsingør, Denmark
Jorgensen BB (1983) Processes at the sediment-water interface. In: Bolin B, Cook RB (eds) The major biogeochemical cycles and their interactions. SCOPE 21 John Wiley \& Sons, Chichester, p 477-509

Kaspari H, Busse W (1986) Oxidative degradation of purines by the facultative phototrophic bacterium Rhodopseudomonas capsulata. Arch Microbiol 144:67-70

Li YH, Gregory S (1974) Diffusion of ions in sea water and in deep-sea sediments. Geochim Cosmochim Acta 38: $703-71.4$

Lindroth P, Mopper K (1979) High performance liquid chromatography determination of subpicomole amounts of amino acids by precolumn fluorescence derivatization with o-phthaldialdehycle. Anal Chem 51:1667-1675

Lomstein BAa, Blackburn TH (1992) Sediment nitrogen cycling in Aarhus Bay, Denmark. The Danish National Environmental Protection Agency, Luna-Tryk Aps, Copenhagen

Lomstein BAa, Blackburn TH, Henriksen K (1989) Aspects of nitrogen and carbon cycling in the northern Bering Shelf sediment. I. The significance of urea turnover in the mineralization of $\mathrm{NH}_{4}^{+}$Mar Ecol Prog Ser 57:237-247

Lund BAa, Blackburn TH (1989) Urea turnover in a coasta marine sediment measured by a ${ }^{14} \mathrm{C}$-urea short-term incubation. J Microbiol Meth 9:297-308

Mantoura RFC, Llewellyn CA (1983) The rapid determination of algal chlorophyll and carotenoid pigments and their breakdown products in natural waters by reverse-phase high-performance liquid chromatography. Analyt Chim Acta 151:297-314

Pedersen OB, Christiansen $C$, Laursen MB (1995) Windinduced long term increase and short term fluctuations of shallow water suspended matter and nutrient concentrations, Ringkøbing Fjord, Denmark. Ophelia 41 : 273-287

Price NM, Harrison PJ (1987) Comparison of methods for the analysis of dissolved urea in seawater. Mar Biol 94: $307-317$

Sloth NP, Riemann B, Nielsen LP, Blackburn TH (1996) Resilience of pelagic and benthic microbial communities to sediment resuspension in a coastal ecosystem, Knebel Vig, Denmark. Estuar Coast Shelf Sci 42:405-415

Sraillie RM, Kratkov G (1960) The estimation of nucleic acids in some algae and higher plants. Can J Bot 38:31-49

Sugai. SF, Henrichs SM (1992) Rates of amino acid uptake and mineralization in Resurrection Bay (Alaska) sediments. Mar Ecol Prog Ser 88:129-141

Therkildsen MS, King GM, Lomstein BAa (1996) Urea production and turnover following the actdition of AMP. CMP, RNA and a protein mixture to a marine sediment. Aquat Microb Ecol 10:173-179

Ullman WJ, Aller RC (1982) Diffusion coefficients in nearshore marine sediments. Limnol Oceanogr 27:552-556

Vogels GD, Van der Drift C (1976) Degradation of purines and pyrimidines by microorganisms. Bacterinl Rev 40 : 403-468

Submitted: April 23, 1997, Accepted: August 3, 1997 Proofs received from author(s): September 2, 1997 